\title{
MOTIVASI BERPRESTASI MAHASISWA DI MASA PANDEMI Oleh:
}

\author{
Syifa'an Kamila \\ Email : syifakmla@gmail.com \\ S1 Psikologi Fakultas Kedokteran Universitas Lambung Mangkurat
}

\begin{abstract}
ABSTRAK
Pada masa pandemi Covid-19 ini, pembelajaran dilakukan secara daring demi memutus rantai penyebaran Covid-19, sehingga mahasiswa dituntut untuk dapat lebih mandiri dalam belajar karena pembelajaran tidak dilakukan secara tatap muka. Pada masa ini, kemandirian belajar merupakan salah satu aspek penting yang harus dimiliki oleh mahasiswa demi tercapainya kompetensi pembelajaan secara optimal. Untuk mencapai kualitas pendidikan khususnya dalam kegiatan pembelajaran perlu menggunakan beberapa prinsip-prinsip pembelajaran yang telah ditetapkan. Bukan hanya dosen yang menyampaikan materi, namun mahasiswak juga ikut andil dalam mengikuti pembelajaran seperti diskusi, memberikan pendapat, memberi pertanyaan, dan lain-lain. Jika mutu pendidikan sudah baik maka motivasi belajar mahasiswa akan meningkat. Mahasiswa akan melakukan hal yang terbaik untuk setiap proses pembelajaran, kemungkinan besar juga akan berdampak pada hasil belajar mahasiswa yang akan lebih baik. Tujuan dari analisis ini adalah untuk mengetahui motivasi berprestasi mahasiswa di masa pandemi. Motivasi ini timbul karena adanya pengaruh dari luar mahasiswa, seperti: adanya ajakan, suruhan, bahkan paksaan dari orang lain, dengan demikian akan mahasiswa akan melakukan sesuatu untuk mencapai target belajar yang optimal.
\end{abstract}




\section{MOTIVASI BERPRESTASI MAHASISWA DI MASA PANDEMI}

Berdasarkan apa yang telah saya baca di buku "Menulis di Era COVID-19" yang ditulis oleh Prof. Ersis Warmansyah Abbas, menulis adalah hal yang mudah. Semua orang adalah penulis. Begitulah ysng disebutkan di buku tersebut. Ketika saya menulis tulisan ini pun, saya masih teringat dengan kalimat "tulislah apa yang dipikirkan, bukan memikirkan apa yang ditulis" yang terdapat di buku tersebut.

Lalu sekarang, topik apa yang akan saya tuangkan? Jujur pada masa pandemi seperti ini, saya sering melihat orang-orang get stressed over everything easily. Saya sendiri pun merasakannya. semakin kesini, hal hal di otak saya, serasa semakin berat. Beban di pundak pun terasa bertambah dari waktu ke waktu. pada akhirnya, hal tersebut berpengaruh terhadap kondisi dan cara saya belajar. Saya menjadi lebih bad tempered, sering dalam keadaan suasana hati yang kurang mengenakan, dan tidak termotivasi untuk melakukan hal apapun. Kemudian, kebiasaan dalam berkomunikasi dan berinteraksi satu sama lain dengan cara bertemu langsung yang seharusnya dilakukan tidak lagi menjadi prioritas ketika terjadinya wabah atau pandemi seperti saat ini. Komunikasi hanya bisa dilaksanakan secara virtual. Saya jadi agak kangen nongki sambil makan jajanan berupa gorengan dengan teman-teman saya.

Seperti yang kita semua ketahui, pada Maret 2020, terjadi kegegeran di seluruh dunia atas wabah virus baru dengan nama COVID-19/virus corona. Pandemi ini lahir saat kita sudah memasuki abad 21, di mana kita sudah mengalami perubahan yang signifikan terkait pemanfaatan teknologi informasi dan komunikasi dalam metode yang digunakan saat pembelajaran. Kita tidak harus melakukan proses pembelajaran dengan tatap muka, tetapi pembelajaran juga dilakukan melalui jaringan atau dikenal dengan istilah pembelajaran dalam jaringan (daring). Pembelajaran daring dapat didefinisikan sebagai pembelajaran yang berlangsung sebagian atau seluruhnya memanfaatkan Internet (Education, 2010). Dampak positif dari dilakukannya pembelajaran daring adalah (1) waktu perkuliahan yang lebih efisien. Mahasiswa dapat belajar di mana saja dan kapan saja, (2) daapat diaksesnya materi pembelajaran dengan cara mudah dan juga lebih inovatif. Dalam kemajuan teknologi hari ini memungkinkan kita untuk belajar sepenuhnya secara online dengan menjalin komunikasi sesama teman sekelas, memperhatikan dan menonton kuliah, serta ikut berpartisipasi dalam diskusi khusus mata pelajaran yang sedang kita ampu.

Di sisi lain, situasi pandemi COVID-19 yang ini dirasa kurang menguntungkan untuk sebagian pihak,. Karena adanya beberapa faktor seperti jaringan yang lelet di sebagian daerah, kadang merasa keteteran dengan banyaknya tugas yang diberikan, sulit berkonsentrasi pada pembelajaran, kuota internet yang terbatas dan membuat mahasiswa terkekang secara pskilogis. Sehingga, kebanyakan mahasiswa (termasuk saya sendiri) lebih senang belajar dengan langsung bertatap muka. Proses belajar secara daring mengharuskan mahasiswa untuk belajar secara mandiri, dengan harapan mahasiswa dapat memiliki kemandirian dalam proses belajar yang baik sehingga mampu mengikuti proses pembelajaran dan mendapatkan hasil belajar yang juga baik. Namun nyatanya, hanya sebagian dari mahasiswa yang memiliki motivasi kemandirian belajar yang baik, ditambah dengan adanya berberapa faktor yang dapat menghambat motivasi kemandirian belajar mahasiswa tersebut. Sehingga, kemandirian mahasiswa dalam belajar masih sangat perlu untuk dikembangkan. Kemandirian belajar itu sendiri merupakan kesadaran dari diri mahasiswa tersebut belajar untuk tidak bergantung kepada orang lain dan merasa bertanggung jawab dalam mencapai tujuan yang diinginkan (Hamka, D. \& Vilmala, B.K.,2019). Seseorang dikatakan mempunyai kemandirian belajar yang baik jika mampu dan dapat mengarahkan pembelajaran mereka sendiri, 
Motivasi dalam bidang akademik biasanya disebut dengan motivasi untuk berprestasi, sebagaimana yang telah dikemukakan oleh McClelland (dalam Sobur,2003) bahwa motivasi berprestasi merupakan jenis motivasi yang paling penting dalam dunia pendidikan (Need of Achievement). McClelland (1987) menjelaskan bahwa motivasi berprestasi adalah suatu usaha untuk mencapai hasil yang sebaik-baiknya dengan berpedoman pada suatu standart keunggulan. Nah, kebutuhan untuk berprestasi merupakan kemampuan mahasiswa untuk melakukan kegiatan yang dengan cara yang cenderung lebih baik, lebih cepat, lebih efektif dan lebih efisien. Mc.Clelland (dalam Djiwandono,2002) menyebutkan motivasi berprestasi terdiri dari beberapa aspek, yaitu: (a) tanggung jawab. Mahasiswa dengan motivasi berprestasi tinggi akan memiliki rasa tanggung jawab yang besar dalam menyelesaikan tugas, sehingga tugas tersebut akan dikerjakannya sampai mendapatkan hasil yang maksimal. Mahasiswa memiliki tingkat tanggung jawab yang berbeda yaitu tinggi, sedang, dan rendah. Mahasiswa yang memiliki tanggung jawab yang tinggi, atau biasanya disebut dengan kaum ambis akan segera menyelesaikan tugasnya secepat mungkin tanpa adanya proskastinasi. Mahasiswa yang memiliki rasa tanggung jawab sedang biasanya ketika memiliki tugas pasti akan dikerjakan tapi dengan tidak terburu-buru, alias tipe mahasiswa santuy asal tidak terlewat dari deadline yang sudah ditentukan. Sedangkan, mahasiswa yang memiliki tanggung jawab rendah biasanya selalu menunggu bantuan dari orang lain dalam mengerjakan tugas atau bahkan tidak dikerjakan; (b) Kreatif. Mahasiwa dengan motivasi berprestasi tinggi akan selalu mencari cara baru dalam bertindak kreatif dan inovatif untuk menyelesaikan tugas sehingga dapat terselesaikan secara efektif dan efisien. Semakin tinggi kreativitas yang dimiliki mahasiswa tersebut, maka semakin besar efforts yang akan dikeluarkannya untuk menyelesaikan tugas tersebut walaupun dia akan meraskan struggles dalam menyelesaikannya. (c) Target. Target adalah motivasi berprestasi yang tinggi dalam diri mahasiswa, untuk membuat dan menetapkan target pencapaian. (d) Semangat. Setiap mahasiswa memiliki tujuan yang berbeda, dan dalam mencapai tujuan juga akan menggunakan caranya masing-masing. Mahasiswa dengan semangat yang tinggi akan segera menuntaskan tujuan yang ingin dicapainya,i begitupun sebaliknya.

Sedangkan, menurut Heckhausen (dalam purwanto 1987) berprestasi merupakan usaha keras mahasiswa untuk meningkatkan atau mempertahankan kecakapan diri setinggi mungkin di setiap aktivitas dengan standart keunggulan sebagai pembanding. Jadi, dari pendapat para ahli diatas, dapat disimpulkan bahwa motivasi berprestasi adalah suatu bentuk usaha yang dilakukan setiap pribadi mahasiswa dalam menyelesaikan tugas atau kegiatan dengan lebih baik, cepat, efektif, dan efisien.

Lingkungan mahasiswa dengan motivasi berprestasi yang baik tidak akan terwujud jika tidak diiringi oleh beberapa faktor utamanya, yaitu tingkat tinggi rendahnya motivasi mahasiswa tersebut untuk belajar dan bagaimana dukungan orang sekitar terhadap mereka. Apalagi di masa pandemi seperti sekarang yang membuat mahasiswa sering kehilangan motivasi dan merasa mudah jenuh. Nah, jadi akan saya sebutkan berberapa persyaratan yang harus dipenuhi dalam pelaksanaan kuliah daring, untuk meminimalisir terjadinya hal yang tidak diinginkan, antara lain: (a) tentu eksistensi dari pihak penyelenggara kegiatan kuliah daring dan para pesertanya, (b) mindset positif dosen dan mahasiswa dalam pembelajaran secara daring agar motivasi berprestasi mudah untuk berkembang, (c) proses belajar yang dapat diterapkan dan digunakan oleh semua pihak (dosen maupun mahasiswa) (d) adanya proses evaluasi dari rangkaian proses belajar, dan (e) adanya feedback dari pihak yang menyelenggarakan.

Pada pembelajaran daring di masa pandemi seperti sekarang, motivasi instrinsik terdiri dari motivasi dalam diri (self-motivation), disiplin diri, adaptasi diri, perasaan acuh tak acuh (feeling indifferent), sedangkan motivasi ekstrinsik terdiri dari pembelajaran daring, dosen/guru, penggunaan media pembelajaran daring, ujian/tugas, keluarga, teman dan lingkungan (Lee et al., 2020). Motivasi seseorang merupakan salah satu penentu keberhasilan dalam pembelajaran, motivasi instrinsik sangat berpengaruh terhadap pembelajaran, khususnya dalam pembelajaran online (Baber, 2020). 
Then, how? Bagaimana cara mahasiswa menumbuhkan motivasi berprestasi di saat perkuliahan daring di masa pandemi?

Caranya adalah dengan belajar untuk dapat melakukan pengaturan/kontrol diri yang baik. Pengaturan diri yang baik menunjukkan bahwa mahasiswa dapat melakukan kontrol atas dirinya sendiri. Kemampuan dalam mengontrol diri menunjukkan seberapa besar kecerdasan emosi yang ia miliki. Ketika mahasiswa dengan kecerdasan emosi yang cenderung tinggi mengikuti perkuliahan, mereka dapat melakukan kontrol diri untuk melakukan hal-hal yang dirasa dapat bermanfaat dan menghindari hal-hal yang dapat menghambat bagi diri mereka. Dengan demikian, mereka dapat memperoleh hasil yang maksimal dalam pembelajarannya di bangku kuliah, atau dengan kata lain mendapatkan IPK yang memuaskan.

Selain dengan belajar untuk meningkatkan pengontrolan diri, komunikasi juga sangat diperlukan pada masa pandemi COVID-19, informasi yang berisi kata-kata maupun ekspresi saling menguatkan satu sama lain akan menumbuhkan rasa empati dan kepedulian antar sesama. Seperti frasa "Virtual Hugs" yang viral semenjak adanya pandemi,„menunjukkan bahwa masih banyak orang yang peduli terhadap sesama. Komunikasi yang dilakukan secara kontinu,akan menumbuhkan motivasi seseorang sehingga cenderung dapat merubah perilakunya dan aktivitasnya. Sehingga, sangat diperlukan untuk saling keeping up antar semua pihak dalam perkuliahan. Saya sendiri pun merasa diri saya lebih bersemangat dan termotivasi saat saya mengerjakan tugas bersama teman-teman saya. Meski, kami hanya bisa mengggunakan media seperti zoom/dengan fitur voice call lewat gawai masing-masing.

Selain itu, apalagi? Karena saya beserta teman-teman yang lain 'diamanahi' untuk membuat suatu tulisan, yang setelah saya ketik sejauh ini ternyata tidak sesusah apa yang saya bayangkan sebelumnya, alternatif stress reliever lain yang juga bisa dilakukan oleh para mahasiswa adalah menulis. Menulis... Menulis bagaimana? Tulislah apa pun yang pernah didengar, dilihat, dicium, dikecap, dan diraba. Memori apapun yang telah diolah di dalam otak kita. Caranya? Ya tuangkan saja semuanya, semisal beban-beban psikologis yang dialami selama kulon (kuliah online), atau bagaimana treatment yang kita terima selama masih daring seperti ini. Saya sendiri pun kadang sering merasa 'beban' karena lingkingan keluarga yang terkadang suka berasumsi macam-macam dengan pemikiran mereka sendiri. Saya 'kan lama-lama ngerasa, saya ini sepeeti buronan saja dalam rumah tersebut.

Selain sebagai stress reliever, menulis juga bisa dijadikan untuk ajang belajar. bukan ajang pamer, ya. Tapi ajang untuk belajar. Ajang untuk memotivasi diri dan membelajarkan diri. Kita dapat menjadikan hal yang terdahulu, kejadian yang terdahulu, prestasi atau kegagalan yang terdahulu sebagai pembelajaran. Kalau baik dikembangkan, kalau buruk dijadikan pembelajaran agar lebih baik.

Kata-kata yang kita tulis juga dapat mewakili kita. Memori-memori kita yang banyak sekali hal abstrak seperti informasi dan pengetahuan di dalamnya, monggo dituangkan dalam bentuk tulisan. Informasi atau pengetahuan mewakili sesuatu di otak kita.

Berdasarkan analisis ala-ala yang telah saya sampaikan di atas, dapat disimpulkan bahwa motivasi berprestasi dapat memacu peran kecerdasan mahasiswa, yang akan mempengaruhi pestasi akademik mahasiswa tersebut. Implikasi dai temuan dalam analisis ini yaitu, mahasiswa dan dosen untuk saling mengoptimalkan proses pembelajaan yang dilakukan saat daring seperti yang terjadi sekarang. 


\section{DAFTAR PUSTAKA}

Abbas, E. W., \& Erlyani, N. (2020). Menulis di Kala Badai COVID-19.

Abbas, E. W. (2020). Menulis di Otak dan Menuliskan Tulisan di Otak.

Abbas, E. W. (2020). Menulis Kenangan Menulis Buku Bersama. Menulis Kenangan Menulis Buku Bersama

Abbas, E. W. (2020). Menulis Artikel Jurnal. Menulis Artikel Jurnal.

Andini, N. F. Dampak Pembelajaran Daring Bagi Mahasiswa Masa Pandemi COVID-19.

Daniati, D., Ismanto, B., \& Luhsasi, D. I. (2020). Upaya Peningkatan Motivasi dan Hasil Belajar Mahasiswa dengan Penerapan Model Pembelajaran E-Learning Berbasis Google Classroom pada Masa Pandemi COVID-19. Jurnal Kependidikan: Jurnal Hasil Penelitian dan Kajian Kepustakaan di Bidang Pendidikan, Pengajaran dan Pembelajaran, 6(3), 601-608.

Fitriani, W., Haryanto, H., \& Atmojo, S. E. (2020). Motivasi Berprestasi dan Kemandirian Belajar Mahasiswa saat Pembelajaran Daring. Jurnal Pendidikan: Teori, Penelitian, dan Pengembangan, 5(6), 828-834.

Kusumaningrum, W., \& Wiyono, B. D. (2020). Hubungan Antara Dukungan Sosial, Kontrol Diri Dengan Motivasi Berprestasi Dalam Penyelesaian Skripsi Mahasiswa. Jurnal BK UNESA, 11(05).

Marvianto, R. D., Ratnawati, A., \& Madani, N. (2020). Motivasi Berprestasi sebagai Moderator pada Peranan Kecerdasan Emosi terhadap Prestasi Akademik Mahasiswa. Jurnal Psikologi, 16(1), 7482.

Muslih, B. (2020). Urgensi Komunikasi dalam Menumbuhkan Motivasi di Era Pandemi COVID-19. Jurnal Penelitian Manajemen Terapan (PENATARAN), 5(1), 57-65.

Nasrah, N., \& Muafiah, A. M. A. (2020). ANALISIS MOTIVASI BELAJAR DAN HASIL BELAJAR DARING MAHASISWA PADA MASA PANDEMIK COVID-19. JRPD (Jurnal Riset Pendidikan Dasar), 3(2), 207-213.

Ningsih, S. (2020). Persepsi Mahasiswa Terhadap Pembelajaran Daring Pada Masa Pandemi COVID19. JINOTEP (Jurnal Inovasi dan Teknologi Pembelajaran): Kajian dan Riset Dalam Teknologi Pembelajaran, 7(2), 124-132.

Sujiwo, D. A. C., \& A'yun, Q. (2020). Pengaruh Pemanfaatan E-learning Terhadap Motivasi Belajar Mahasiswa. JUSTINDO (Jurnal Sistem dan Teknologi Informasi Indonesia), 5(2), 53-59.

WARMANSYAH ABBAS, E. R. S. I. S. (2020). Menulis di Era COVID-19: Memanage Trauma Psikologis Menghindari Psikosomatis. Menulis di Era COVID-19: Memanage Trauma Psikologis Menghindari Psikosomatis.

Yuliati, Y., \& Saputra, D. S. (2020). Membangun Kemandirian Belajar Mahasiswa melalui Blended Learning di Masa Pandemi COVID-19. Jurnal Elementaria Edukasia, 3(1). 